\title{
Internal Capital Market Efficiency of Belgian Holding Companies ${ }^{\dagger}$
}

\author{
Axel Gautier*\& Malika Hamadi**
}

January 4, 2005

\begin{abstract}
In this paper, we raise the following two questions: (1) do Belgian holding companies operate an internal capital market to transfer financial resources in between their subsidiaries? And if yes, (2) is the internal capital market efficient? To answer the first question, we check if the group cash flow is a determinant of the investment's spending of group members. The answer is positive if the holding's subsidiary is affiliated to a coordinate center and negative otherwise. To answer the second question, we evaluate if internal transfers are driven by efficiency. From our estimations, we cannot conclude that Belgian Holding companies have an efficient internal capital market.
\end{abstract}

Keywords: Investment, Holding, Internal capital market.

JEL Classification: G31

\footnotetext{
${ }^{\dagger}$ Authors are thankfull to seminar and conference participants at VUB (Brussels) and at the LYFRD (Leuven). This research is part of a programme supported by the Belgian government (Poles d'Attraction inter-universitaires PAI P5/26). We are grateful, as well, for the financial support from the Belgian French Community's program 'Action de Recherches Concerte' ARC 03/08-302. Correspondence to Axel Gautier, CORE, 34 voie du Roman Pays, 1348 Louvain-la-Neuve, Belgium. Email: gautier@core.ucl.ac.be.

${ }^{*}$ CEREC, Facultés Universitaires Saint-Louis and CORE.

** IRES, UCL Department of Economics, Louvain-la-Neuve.
} 


\section{Introduction}

There is a large debate to determine whether diversified firms create or destroy value. So far, most of the literature concentrates on US conglomerate firms. ${ }^{1}$ Central to this debate is to determine if the conglomerate's internal capital market (the conglomerate's capital budgeting procedure) is efficient or not. An inefficient internal capital market could explain the apparent diversification discount (Scharfstein and Stein, 2000 and Rajan, Servaes and Zingales, 2000).

To evaluate the effectiveness of the conglomerates' capital budgeting process, the empirical analysis either compares the investment levels of a conglomerate division with a stand alone counter-part (Scharfstein, 1998 and Maksimovic and Philips, 2002) or analyzes if internal transfers are driven by efficiency (Shin and Stulz, 1998). In this paper, we apply the Shin and Stulz's methodology to a panel of Belgian holding companies (BHC).

Diversified companies in Europe are organized as holding companies and not as conglomerate firms. There are two main differences between a holding and a conglomerate firm. First, each business segment of a holding is organized within an independent firm rather than a conglomerate division. Second, voting rights and cash flow rights are separated in holdings. US conglomerates hold typically $100 \%$ of their subsidiaries with a well-defined corporate policy while holding companies can exert control over a subsidiary with a diluted participation in the ultimate business enterprise. Holdings however differ from US closed-end funds or UK investment trusts by their implication in the management of the subsidiaries they own. ${ }^{2}$ In this paper, we investigate whether or not BHC create an internal capital market and if they do if their internal capital market is efficient or not.

\section{The conglomerate controversy}

In their seminal paper, Berger and Ofek (1995) compare the value of multi-division firms with the value of comparable firms acting as stand-alone. They found that US diversified firms trade in average at a 12-15\% discount compared to a portfolio of stand-alone firms replicating the conglomerates' divisions. Lamont and Polk (2002) report similar evidences that diversification destroys value by analyzing the relation between diversity and the firm's value. ${ }^{3}$ For Villalonga (2004a, 2004b), this apparent conglomerate discount is an artifact from the data and she provides

\footnotetext{
${ }^{1}$ Exceptions are Lins and Servaes (2002) for emerging markets, Lins and Servaes (1999) for international evidences from UK, Japan and Germany, Doukas, Holmen and Travelos (2002) for Swedish firms, Fleming, Oliver and Skourakis (2003) for diversified firms in Australia, Siaens and Walravens (1993), Praet (2002) and Colmant, Detournay and Servaty (2003) for Belgian holding companies.

${ }^{2}$ Colmant, Detournay and Servaty (2003), Wymeersch (1994).

${ }^{3}$ See also the evidences of Lang and Stulz (1994).
} 
new evidences that turns the conglomerate discount to a premium. ${ }^{4}$

In a diversified firm, if the divisions operate in different business segments, economies of scale and scope are absent and negative synergies cannot explain the lost value. The literature offers two explanations for the conglomerate discount: first, the decision to diversify or not a firm depends on some of the firm's specific characteristics. Following this argument, the process of conglomeration is endogenous. Some firms do decide to diversify while others, with different characteristics, remain focused. Maksimovic and Phillips (2002) identify the distribution of the firm's markets specific 'talents' as a key determinant of diversification decisions. Agrawal and Samwick (2003) link managerial preferences for empire to diversification decisions. Chevalier (2004) provides evidences that diversification is indeed endogenous. Second, the literature solves the conglomerate discount puzzle by pointing out specific features of conglomerate firms that differentiate them from focused firms. A specific feature of multi-division firms can explain the apparent conglomerate's discount (or premium). Among those, the capital budgeting procedures, the internal capital market (ICM), occupies a prominent place. Berger and Ofek (1995), Lamont (1997) for diversified oil companies, Scharfstein (1998) and Scharfstein and Stein (2000) argue that conglomerate firms inefficiently cross-subsidized low performing segments with the resources of high performing ones. Scharfstein (1998) uses a matching sample method i.e. he compares a conglomerate division with a stand alone counterpart and finds evidences of inefficient cross-subsidization in multi-division firms. In high productivity segments, a conglomerate division invests systematically less than its stand-alone counterpart, while in low productivity segments, a conglomerate division invests more. Using plant-level data, Maksimovic and Phillips (2002) do not find evidence of inefficient cross-subsidization within conglomerates. Chevalier (2004) replicates the results of Scharfstein (1998) with data on firm that will merge in the future and explains the apparent patterns of cross-subsidization by a selection bias in the sample.

Against the inefficient cross-subsidization hypothesis, Williamson (1975), Stein (1997) and Gertner, Scharfstein and Stein (1994) argue that the allocation of capital inside a firm, by the corporate headquarter, is more efficient than the allocation of capital by an outside investor (a bank for example) due to the superior information of the firm's insiders. Conglomerates are then able to create value thanks to their more efficient capital budgeting procedures. On the other hand, Scharfstein and Stein (2000) and Rajan, Servaes and Zingales (2000) argue that the allocation of capital inside conglomerate is not driven by efficiency but by power struggles. If the conflicts between the divisional managers and the corporate owner cannot be solved

\footnotetext{
${ }^{4}$ Campa and Kedia (2002) control for the endogeneity of diversification decisions and they do not found evidence that diversification by itself destroys value.
} 
by incentive contracts, the capital allocation is distorted to reduce those conflicts. Hence, an inefficient capital allocation causes the conglomerate discount. Inderst and Laux (2001), Brusco and Panunzi (2003) and Gautier and Heider (2002) show that an efficient redistribution of resources is associated with additional agency costs. Hence, despite a more efficient capital allocation, a conglomerate could destroy value.

Shin and Stulz (1998) analyze if internal transfers inside a conglomerate are driven by efficiency. A capital budgeting procedure is said to be efficient if the scarce resources are allocated to the projects with the highest value. The ICM is efficient when the headquarter picks the winners (Stein, 1997). As it is defined, the allocation of resources depends only on the total amount of resources available to the firm and the projects' expected returns. It does not depend on the origin of cash flows inside the firm. However, Shin and Stulz found, in data from US conglomerate firms, that the investment of a segment is six times more sensible to the segment's own cash flow than to the other segments' cash flows and cannot conclude that the ICM is efficient.

\section{Internal capital market and diversification discount in continental Europe and in Belgium}

Lins and Servaes (1999) report that the negative effect of diversification on firm value is smaller for German firms than for US, UK and Japanese companies. A possible explanation is that the ownership concentration observed in Germany reduces agency problems. In Belgium, it is well-known that Belgian holding companies trade at a significant discount compared to their net asset values. Siaens and Walravens (1993) and more recently Colmant, Detournay and Servaty (2003) evaluate the holdings' discount. They report an average discount of $23 \%$ for the period 1983-2002 with important variations across holdings and over time. They do provide explanations for the discount that are not linked to the ICM efficiency.

Praet (2002) applies the matching sample method of Scharfstein (1998) to Belgian holding companies and finds that: (i) the subsidiaries of holding have lower performance than family owned companies. (ii) Subsidiaries of holding do not invest less (nor more) than family owned companies. And (iii) the investment in the subsidiary of a holding depends less on its own cash flow, as can be expected when an internal capital market is created. Like Praet, Deloof (1998) documents that BHC have an active ICM: the holding effectively transfers resources between its subsidiaries. However, the instruments used for making these transfers are not clearly identified ${ }^{5}$ nor if these transfers aim to increase the holding's value.

This paper

\footnotetext{
${ }^{5}$ But financial fixed investment is not the way used by BHC to transfer surplus on the internal capital market, Deloof (1998)
} 
This paper tests the inefficient cross-subsidization hypothesis for BHC. To test the efficiency of the holding's internal capital market, we closely follow Shin and Stulz (1998). We construct a sample of BHC and their subsidiaries and test (1) whether or not holdings do transfer resources between their subsidiaries and (2) if those transfers are driven or not by efficiency.

To answer the first question, we check if the group cash flow is a determinant of the investment's spending of group members. More specifically, we estimate the investment cash flow sensitivity with respect to both own and group cash flow. If the latter is positive, the holdings do effectively transfer resources between their subsidiaries.

In our estimations, we find that both the own and the group cash flow are determinant of the investments. Consequently, we can conclude that BHC do effectively transfer resources between their subsidiaries. But not all the holdings do operate an ICM. The investment sensitivity to group cash flow is positive and significant only if the holding's subsidiaries are affiliated to a coordinate center. Coordination-centers allow multinational groups to carry out a large variety of financial and management services on a roughly tax-free basis. The principal activity of coordination-centers is to finance investment of the group members. Loaned funds from coordinate-centers may come from capital of coordinate-center or from financial institutions or from affiliated companies. The coordination centers are used by BHC to transfer their resources in between the subsidiaries i.e. to operate an internal capital market. Conversely, without a coordination center, the holding's subsidiaries have to rely on their own resources only to finance their investments. We do not observe significant transfers in holdings without coordination centers.

According to Shin and Stulz (1998) and Stein (1997), if a holding settles an internal capital market, the funds are efficiently invested if the resources are spent in the most valuable projects (winner-picking). Winner-picking implies that when assessing which projects will be financed, the headquarter bases its decisions not only according to the project's risk and return but also according to the relative merits of the project compared to the other projects available in the holding. Winner-picking (or efficiency) implies that investment spending in a subsidiary should be positively affected by its investment opportunities but negatively affected by the other group member's investment opportunities. Moreover, efficiency requires that the investments should be based only on the relative investment opportunities and not be based on the origin of resources within the holding. Hence, we check these relations to answer our second question.

There are substantial departures from winner picking in BHC. The origin of cash flow remains an important determinant of investment within holdings. Hence, BHC do not have an efficient ICM. However, it does not mean that BHC cross-subsidize low performing divisions with 
the resources of high performing ones. We try to clarify this point, by estimating separately the determinant of investment in low and high performance subsidiaries. We found that low performing subsidiaries rely more on group financing and less on own financing that high performing subsidiaries. This could be explained either as an evidence for the cross-subsidization hypothesis or by the strong correlation between cash flow and the variable measuring the opportunities. To clarify this, we split the sample according to the subsidiary's performance. We found that the investment of firms with a lower performance has a lower sensitivity to its own cash flow and a higher sensitivity to the group cash flow. According to Fazzari, Hubbard and Petersen (1988), the investment cash flow sensitivity is a measure of the firm's credit constraint. Hence, in a holding with an efficient internal capital market, funds should be allocated in priority to the high performance division and thereby, we should observe a lower investment (total) cash flow sensitivity for high performance divisions. In the data, we found the opposite and then, we cannot conclude that BHC have an efficient ICM.

Using a methodology similar to Shin and Stulz (1998) for non US diversified firms is interesting for at least two reasons: first, diversified companies in Europe, Belgium being a prime example, are organized as holding companies rather than as conglomerate companies. In a holding, each activity is organized as an independent firm and as such it is subject to the same accounting obligations as any other firm. The holding firm has no discretion in reporting the segment data neither in defining segments. While US conglomerates are required to report segment data only if it accounts for $10 \%$ or more of its consolidated profits, assets or sales and their managers have some discretion in disclosing segment level data. The $10 \%$ threshold implies that a conglomerate cannot report more than 10 business segments. Villalonga (2004b) shows that these institutional constraints together with the managerial discretion give a false picture of diversified companies and could explain the apparent diversification discount, which is then an artifact from the data. In our sample, there is no problem of this kind as the holding management does not control the disclosure rule and the segment definition. The average number of holding subsidiaries, in our sample, is 4 and the max is 25. Second, in Belgium the external capital markets are poorly developed. Market capitalisation of Belgian firms accounted only for $45 \%$ of GDP in 1996. Holding companies then act as substitutes for capital markets. Bank loans and intra-group loans are major sources of external financing (Deloof, 1998, 2001). Following Fazzari, Hubbard and Petersen (1988), the investment cash flow sensitivity depends on the credit constraints faced by the firm. Hence, internal financing of investment spending, including financing by other group members, is of prime importance in Belgium. Consequently, firms belonging to a corporate group, for which the investment is partially financed on an inter- 
nal capital market of the group, are not to the same degree subject to financing constraints as firms which have to borrow from banks (Deloof, 1998). ${ }^{6}$ The efficiency of the capital budgeting procedure would then have even more impact on the value of a diversified holding when external funds are difficult to attract.

\section{Empirical methodology}

Concerning Belgian holding companies, we raise the following questions: (1) do Belgian holding companies operate an internal capital market to transfer their resources in between their subsidiaries ? And if yes, (2) is the internal capital market efficient? Internal capital market efficiency meaning that the holding's resources are invested in the most profitable segments. To answer these two questions, we estimate the following equation:

$$
\frac{I_{i K}(t)}{T A_{i}(t)}=\alpha_{1} \frac{C F_{i K}(t)}{T A_{i}(t)}+\alpha_{2} \sum_{j \neq i \in K} \frac{C F_{j}(t)}{T A_{i}(t)}+\alpha_{3} \theta_{i K}(t)+\alpha_{4} \theta_{K}(t)+\alpha_{5} \log T A_{K}(t)+\eta_{K}+\epsilon_{i K}(t)
$$

Where the variables are defined as follow :

- $\frac{I_{i K}(t)}{T A_{i}(t)}$ is the investment in fixed assets of the subsidiary $i$ of holding $K$ at year $t$ divided by its total assets at year $t$.

- $\frac{C F_{i K}(t)}{T A_{i}(t)}$ is the cash flow of the subsidiary $i$ of holding $K$ at year $t$ divided by its total assets at year $t$.

- $\sum_{j \neq i \in K} \frac{C F_{j}(t)}{T A_{i}(t)}$ is the sum of the cash flow of the subsidiaries $j \neq i$ of holding $K$ at year $t$ scaled by the total assets of subsidiary $i$ at year $t$.

- $\theta_{i K}(t)$ is a measure of the investment's opportunities of subsidiary $i$ at year $t$. We use the subsidiary's return on assets (ROA) to approximate the investment's opportunities in subsidiary $i .^{7}$

- $\theta_{K}(t)$ is a measure of the investment's opportunities of holding $K$ outside subsidiary $i$ at year $t$. It is approximated by the highest ROA of subsidiary $j \neq i \in K$. The highest ROA represents the best use of resource in the holding outside subsidiary $i$.

\footnotetext{
${ }^{6}$ This is confirmed by Praet (2002) who founds a lower cash-flow sensitivity for holdings' subsidiaries than for family owned companies.

${ }^{7}$ We also use the sales growth to measure the investment opportunities but this turns to be inconclusive.
} 
- $\log T A_{K}(t)$ is the $\log$ of all total asset of subsidiaries $j$ of holding $K$. It is a proxy for the holding size. This variable is used as a control variable. In addition, we use the investment in financial fixed assets scaled by total assets $\left(F F A_{i}(t) / T A_{i}(t)\right)$ as another control variable.

- $\eta_{K}$ is a firm specific effect (unobserved effect).

- $\epsilon_{i K}(t)$ is an error term.

The estimated equation is similar to Shin and Stulz (1998). The main difference is that Shin and Stulz measure the investment opportunities by sales growth and the segment's Tobin's q. ${ }^{8}$ Compared to the Tobin's q, the measure we use for the investment opportunities (ROA) does not take the risk into account. Nevertheless, we are not able to compute the segment's Tobin's q for the subsidiaries of BHC, since almost all the subsidiaries are not listed in the stock market.

If $\mathrm{BHC}$ operate an internal capital market, the investment in a subsidiary $i$ should depend on both its own cash flow and the cash flow of the other subsidiaries of the holding. A positive sign for the coefficient $\alpha_{2}$ will then mean that BHC have an active internal capital market. Conversely, if the holding does not transfer resources between its subsidiaries, the investment in subsidiary $i$ should be independent of the other group cash flow: $\alpha_{2}=0$.

Concerning the efficiency of the internal capital market, according to Shin and Stulz (1998) an internal capital market is efficient "if investment by a segment depends only on firm cash flow after controlling for its investment opportunities, a dollar of cash flow should have the same impact on the investment by a segment irrespective of its source within the firm" (pages 534-535). This means that (i) the subsidiaries' investments should depend on the total resources available in the holding ${ }^{9}$, and (ii) an increase in the investment opportunity of subsidiary $i$ should lead to a rise in the investment $I_{i K}$ and a fall in the investments $I_{j K}, j \neq i$. Shin and Stulz's definition of efficiency corresponds to:

- $\alpha_{1}>0, \alpha_{2}>0, \alpha_{1}=\alpha_{2}$.

- $\alpha_{3}>0$ and $\alpha_{4}<0$.

If the firm is credit constrained, i.e. it does not have free cash flow ${ }^{10}$, the holding cannot finance all the subsidiaries' investment projects with its scarce resources. Hence, the top management should make critical choices concerning the use of the resources. These choices are

\footnotetext{
${ }^{8}$ They use the median q of specialized firms in the segment's industry.

${ }^{9}$ By scaling the own and the the group cash flows by the total asset of subsidiary $i$, we make the two variables comparable.

${ }^{10}$ Jensen (1986).
} 
efficient if the investment levels are driven only by the subsidiaries opportunities. A holding with limited resources has an efficient internal capital market if the holding's headquarter organizes a winner picking/loser sticking contest (Stein, 1997): "simply put, individual projects must compete for the scarce funds, and the headquarters' job is to pick the winners and the losers in this competition", (page 111). Winners and losers are determined by their relative investment opportunities. "Specifically, the extent to which any given project gets funded in an internal capital market will depend not only on that project's own absolute merits, but also on its merits relative to other projects in the company's overall portfolio", Stein (1997), page 112. Hence, if the holding is credit constrained and if the internal capital market is efficient, we should observe $\alpha_{3}>0$ and $\alpha_{4}<0$. If the holding has free cash flow, it could finance all its investment projects and hence, we should observe $\alpha_{3}=0$ and $\alpha_{4}=0$.

Observing $\alpha_{1} \geq \alpha_{2}>0$ is not necessarily incompatible with ICM efficiency. There are two reasons for that. For Brusco and Panuzzi (2003), $\alpha_{1}>\alpha_{2}$ is not incompatible with an efficient internal capital market when there are agency problems between the management of the holding and the managers of its subsidiaries. An agency problem arises when (i) the managerial reward is tied to the performance of its subsidiary and (ii) the manager can influence the cash flow level by exerting an unobservable effort. If the holding management pools all the subsidiaries' cash flows, managerial incentives to exert effort are weak since the manager receives for investment only a fraction $\alpha_{1}$ of any additional resource produced in its subsidiary. The internal capital market expropriates a fraction of managerial effort. Pooling all the firm's resources reduces the incentive to create those resources. If the holding management raises $\alpha_{1}$ above $\alpha_{2}$, resources might be less efficiently allocated ex-post, but it stimulates resource production by the manager by leaving a larger fraction of the resources created for investment. Making the investment of a subsidiary dependent on the realized cash flow in this subsidiary stimulates the managerial incentives to produce cash flow.

Moreover, the firm's cash flow could also be a proxy for the firm's investment opportunity. Accordingly, observing $\alpha_{1}>\alpha_{2}$ within a holding firm would simply reflect the fact that investment depends on opportunities (measured by cash flow). Correlation between cash flow and investment opportunity could lead us to over estimate the influence of cash flow on investment levels. Hence, we cannot exclude that observing $\alpha_{1}>\alpha_{2}$ reflects poor measures of opportunities. 


\section{Data source}

We use the "centrale des bilans" database of the National Bank of Belgium (NBB). It contains the annual accounts and other accounting data of all Belgian firms. Ownership data is also recorded. The data covers the period 1991-1996. 1991 is the date at which the disclosure law becomes compulsory for all firms listed without exception. ${ }^{11}$

To construct the database, we select all Belgian listed companies that report to be a holding. The definition of the holding is given by the Belgian Stock exchange. ${ }^{12}$

The NBB's database contains financial data of BHC and their Belgian and Luxembourg subsidiaries. It also contains ownership data on subsidiaries outside Belgium and Luxembourg but no financial data. Our sample then consists of financial data of BHC and their Belgian and Luxembourg subsidiaries. We include control variables to take into account the missing information on foreign subsidiaries. In particular, we control for the number and the proportion of foreign subsidiaries.

\subsection{Sample description}

Our sample consists in all the Belgian and Luxembourg subsidiaries of all Belgian listed holding companies that satisfy the following criteria:

1. The subsidiary should report annual accounts to the NBB. Subsidiaries that are found in the statements of ownership (the holding's participation record) but not when we search for their annual accounts are excluded from the sample.

2. Subsidiaries in the financial sector (NACE code beginning by 8) and in other services sectors as education for example (NACE code beginning by 9) are excluded from the sample.

3. We eliminate the subsidiaries for which the holding companies does not have control. A holding controls a subsidiary for sure if it has at least $50 \%$ of shareholding directly and/or indirectly. If there is a direct and an indirect shareholding by the mother company in the subsidiary we take the sum of both. However, through pyramidal structure, a mother company can achieve much control over the subsidiary with only a little indirect

\footnotetext{
${ }^{11}$ The disclosure law was adopted in 1989 and before this date the Belgian corporate ownership was a dark box, no data were available and little was known about it. Some firms, under condition, were not obliged to disclose their ownership data. By the end of 1991 the notification to the Banking Commission was compulsory for all firms.

${ }^{12}$ Sector 27 in the Belgium stock exchange classification.
} 
shareholding. For example if a holding A holds $50 \%$ in a subsidiary A1 and $20 \%$ in a subsidiary A2, and if A1 holds 30\% in A2, the sum of direct and indirect shareholding of A2 is $35 \%$ but the holding effectively exerts control over A2. Thereby, we assume that the holding exerts the control if it has at least $20 \%$ of direct and indirect shareholding in a subsidiary. Although, the mother company can achieve much control over the subsidiary with only a little indirect shareholding through pyramids, we have chosen $20 \%$ because it represents a critical threshold. Under the Belgian law if the shareholding in a company reaches $20 \%$ of voting rights upward or downward, the shareholder has to join to his notification to the Banking Commission and to the target company, the policy statement explaining the strategic intent with regard to the target. Two remarks are in order: first, the results are qualitatively the same when we use the $20 \%$ threshold and the $50 \%$ threshold. Hence including the subsidiaries where the ownership stake is in between $20 \%$ and $50 \%$, does not change the results but increases the sample size. Second, in the sample, the mean ownership stake is $83 \%$ and in more than $75 \%$ of the subsidiaries, the holding exerts control with more than half of the shares.

4. If after the steps described above, a holding remains with only one subsidiary, we exclude it from the sample. As our study is about ICM and transfers between subsidiaries, a holding with only one subsidiary is meaningless.

The selection procedure described above results in a sample for the period from 1991 to 1996 of 105 holding companies with 434 subsidiaries. The mean investment in fixed assets represents $5 \%$ of the total assets. Note that $10 \%$ of the companies/year in the sample have a zero investment level. Table 1 presents the univariate analysis of the sample.

\section{Empirical results}

We conduct panel data estimations with fixed effects and we include the year dummies. For commodity, the coefficients of the year dummies are not reported. Table 2 contains the results of the first estimation. The variables own cash flow and other cash flow are both positive and significant. ${ }^{13}$ Group cash flow is a then significant determinant of the subsidiaries' investment. It confirms that Belgian holding companies operate an internal capital market and that they

\footnotetext{
${ }^{13}$ And comparable to the estimated investment cash flow sensitivity realized in other studies; the estimated investment (own) cash flow sensitivity ranges from 0.12 to 0.15 in Shin and Stulz (1998), from 0.20 to 0.47 in Van Cayselle (2002) and is equals to 0.007 for holding subsidiaries in Praet (2002).
} 
do transfer resources for investment in between their subsidiaries. ${ }^{14}$ Investment is partially financed by the group resources in Belgian holding companies. The control variables for foreign subsidiaries are not significant (and not reported in the tables). Then, the holding's specific effect $\left(\eta_{K}\right)$ captures all the impact of foreign subsidiaries on the belgian subsidiaries' investment.

The estimated ratio $\frac{\alpha_{1}}{\alpha_{2}}$ is approximately equal to 7.4, meaning that the own resources are 7.4 times more important that the group resources for explaining investment. ${ }^{15}$ There is a significant dependence of the investment on the origin of cash flow. It therefore implies that the allocation of resources inside the holding departs from a winner picking contest where the scare resources would have been allocated to the most efficient investment projects independently of their origin within the holding. Holding companies do not pool all their resources before reallocating them to investment projects but rather leave a significant fraction of resources for investment within the subsidiaries. Group financing accounts for only a relatively small fraction of the investment compared to the own financing. A limited financing from the group is also a tool for the holding's management to increase the incentives to create resources at the subsidiary level. ${ }^{16}$

Group financing is limited, but is it efficient? To see if the intra-group transfers are driven by efficiency, we look at the variable measuring investment opportunities. Surprisingly, the investment opportunity of a subsidiary has a negative impact on its investment. The estimated coefficient of own ROA is negative and significant. This suggests that internal transfers are not efficient and that holding do cross-subsidization of low performing subsidiaries with the resources of high performing one. But, high investment opportunities elsewhere in the holding has a negative and significant impact on the investment. The higher the return on asset of the holding's most profitable subsidiary, the lower the investments in the other holding's subsidiaries. This suggests that high profitable segments attract the group resources. The presence of highly profitable segment in the holding reduces the investment of the relatively less profitable segments. This evidence suggests that internal transfers are efficient. To clarify this point, we split the sample in two sub-samples. In a first one, we keep the subsidiaries with a ROA above the median; the remaining subsidiaries are put in a second one. Highly profitable subsidiaries attract more group resources than lower profitable one if the coefficient $\alpha_{2}$ is larger when it is estimated using the first sub-sample than the second. As shown in table 2, it is not the case, the estimated

\footnotetext{
${ }^{14}$ Praet (2002) establishes the same by showing that the investment cash flow sensitivity is lower for a holding's subsidiary than for a family owned company. Similarly, Deloof (1998) shows that the investment cash flow sensitivity is lower for subsidiaries which can finance their investment by borrowing on the internal capital market than for firms which have to borrow on external capital market (typically bank financing).

${ }^{15}$ Shin and Stulz (1998) found a comparable ratio of 6 for US conglomerates.

${ }^{16}$ Brusco and Panunzi (2003)
} 
coefficient $\alpha_{2}$ is three time larger for the subsidiaries with a ROA below the median than for the subsidiaries with a ROA above. Moreover, the impact of the own cash flow is larger for subsidiaries with a high ROA. From that, we cannot conclude that the internal capital market is efficient. The investment total (group+own) cash flow sensitivity is greater for subsidiaries with a low ROA. Fazzari, Hubbard and Petersen (1988) measures the firm's credit constraint by its investment cash flow sensitivity. Accordingly, if the holding has an efficient ICM, we should observe a lower credit constraint for the more efficient subsidiaries. However, we found the reverse in the data.

These results could partially be explained by the high correlation between the cash flow and the investment opportunities. The variables own ROA and own cash flow are highly correlated (around 89\%). High correlation could lead to an overestimation of the coefficient $\alpha_{1}$. To control for that, we add an interaction variable between own cash and own ROA, but the variable is not significant and its addition does not change the results. As another proxy for growth opportunities we use sales growth instead of own ROA. However, the results are not statistically significant (and not reported here). Moreover, the sample size is reduced when we use sales growth because we loose a part of the data due to the lag introduced.

There is also a crowding out of investment in fixed assets by the investment in financial assets. The investment in financial assets reduces the investment in fixed assets. This effect is particularly important for low ROA subsidiaries. Even if the hypothesis is rejected by Deloof (1998), investment in financial fixed assets could be used by a holding to transfer resources between subsidiaries. In that sense, it is not a surprise to observe negative sign for the variable $F F A$. The coefficient is negative and significant only for the subsidiaries that have a ROA below the median. Hence, this together with the negative sign of the variable Highest ROA could suggest that low ROA subsidiaries transfer their resources to higher ROA subsidiaries within the group. This would be against the inefficient cross-subsidization hypothesis. To investigate further the role of credit constraints, we split again the sample in two sub-samples. The first one contains the holdings that are relatively less credit constrained, the second one contains the holdings that are relatively more credit constrained. Group financing is expected to be more important in holdings facing stronger credit constraint. Results are reported in table 3.

To measure credit constraint, we use the ratio of holding's total cash flow to holding's total assets. This ratio measure the availability of internal funds compared to total assets. In our estimation, we find that the coefficient of group cash flow is similar in the two subsamples, but more significant for highly constrained firms. The coefficient of own cash flow is 
surprisingly larger for the subsidiaries of holdings with high ratio. Less surprising is the impact of financial fixed assets: for highly constrained firms, the investment in financial assets reduces the investment in fixed assets, while it does not have an impact for firms with low credit constraint.

Now that it is established that BHC have a significant group financing of investments, a natural question is to see if all the holdings do operate an internal capital market. In table 4, we report the estimation for holdings that are related and those who are not related to a coordinate center. Coordination centers are created within multi national groups to carry on a series of financial operations, including investment financing. For the holdings that are not affiliated to a coordinate center, the variable other cash flow is not significant. It is significant for holdings related to a coordinate center. Group financing accounts for investment only if the holding has a coordinate center. The data suggests that holdings which are not affiliated to a coordinate center do not operate an internal capital market. A coordinate center seems necessary for a holding to transfer its resources between its subsidiaries. Without coordinate center, the cash flows cannot be (easily) transferred between the subsidiaries and the investment is not explained by the holding's resources. ${ }^{17}$ Likewise, the variable group cash flow is not significant for holdings with less than 5 belgian subsidiaries. Hence, we do not find evidences that all the holdings operate an ICM.

\section{Concluding remarks}

Our estimations confirm that Belgian holding companies transfer resources between their subsidiaries on an internal capital market and the answer to our first question is affirmative. We also show that coordinate centers play an important role in the setting up of an active internal capital market. The holdings use their coordinate centers to transfer resources for investments in fixed assets in between their subsidiaries.

The answer to the second question concerning the efficiency of transfers is less clear cut. We observe substantial departures from winner picking in the redistribution of resources inside the holding. Own financing remains proportionally more important than group financing. This does not mean that these limited transfer are inefficient i.e that high performing divisions finance low performing ones. We observe that subsidiaries with low opportunities rely relatively more on group financing that subsidiaries with high opportunities. This could be interpreted either as a sign of inefficient cross-subsidization or as a sign of correlation between resources and opportunities. In this second scenario, low performing firms lacks off financial resources and

\footnotetext{
${ }^{17}$ Moreover, the own cash flow is not always significant.
} 
rely on the excessive resources of high performing ones. To validate this hypothesis, we should observe that high performing divisions are less credit constrained than low performing ones. Accordingly, high ROA subsidiaries should have a lower investment own cash flow sensitivity. The data show that it is not the case. Hence, we cannot conclude that the holdings' internal transfers are efficient. 
Table 1: Univariate analysis.

\begin{tabular}{|c|c|c|c|c|}
\hline Variables & Mean & $25^{\text {th }}$ percentile & $50^{t h}$ percentile & $75^{\text {th }}$ percentile \\
\hline \multicolumn{5}{|l|}{ Investment } \\
\hline$I_{i}(t) / T A_{i}(t)$ & 0.0507 & 0.0001 & 0.0142 & 0.0508 \\
\hline \multicolumn{5}{|l|}{ Own cash flow } \\
\hline$C F_{i}(t) / T A_{i}(t)$ & -0.0789 & -0.0099 & 0.0448 & 0.0989 \\
\hline \multicolumn{5}{|l|}{ Other cash flow } \\
\hline$\sum_{j \neq i \in K} C F_{j}(t) / T A_{i}(t)$ & -0.1282 & -0.0407 & 0.1531 & 0.4088 \\
\hline \multicolumn{5}{|l|}{ Own ROA } \\
\hline$\theta_{i}(t)$ & -7.759609 & -2.28186 & 1.66005 & 6.28500 \\
\hline \multicolumn{5}{|l|}{ Highest ROA } \\
\hline$\theta_{K}(t)$ & 11.2747 & 3.0850 & 7.8885 & 16.5597 \\
\hline \multicolumn{5}{|l|}{ Financial fixed assets } \\
\hline$F F A_{i}(t) / T A_{i}(t)$ & 0.1867 & 0.0006 & 0.0084 & 0.3455 \\
\hline \multicolumn{5}{|l|}{ Group size } \\
\hline $\log T A_{K}(t)$ & 9.7315 & 9.2358 & 9.5902 & 10.2669 \\
\hline \multicolumn{5}{|l|}{ Sales growth } \\
\hline$\frac{S_{i}(t)-S_{i}(t-1)}{S_{i}(t-1)}$ & 0.5127 & -0.06701 & 0.04208 & 0.2934 \\
\hline \multicolumn{5}{|c|}{$i, j \in K$ refers to subsidiary $i, j$ of holding $K . t$ refers to time. } \\
\hline \multicolumn{5}{|c|}{$T A_{i}(t)$ is the total asset. of $i \in K$ at $t$. } \\
\hline \multicolumn{5}{|c|}{$I_{i}$ is the investment in fixed assets of $i \in K$ at $t$. } \\
\hline \multicolumn{5}{|c|}{$C F_{i}(t)$ is the cash flow of $i \in K$ at $t$. } \\
\hline \multicolumn{5}{|c|}{$\sum_{j \neq i \in K} C F_{j}(t)$ is the sum of the cash flow of $j \neq i, j \in K$ at $t$. } \\
\hline \multicolumn{5}{|c|}{$\theta_{i}(t)$ is the return on assets (ROA) of $i \in K$ at $t$} \\
\hline \multicolumn{5}{|c|}{$\theta_{K}(t)$ is the highest ROA of $j \in K$ at $t$ with $j \neq i$. } \\
\hline \multicolumn{5}{|c|}{$F F A_{i}(t)$ is the investment in financial fixed assets of $i \in K$ at $t$. } \\
\hline \multicolumn{5}{|c|}{$\log T A_{K}(t)$ is the $\log$ of all total asset of $j \in K$ at $t$. } \\
\hline$S_{i}(t)$ is the sales of $i \in$ & r at $t$. & & & \\
\hline
\end{tabular}


Table 2: Panel data regression with fixed effects of the investment of all subsidiaries from 1991 to 1996 as a linear function of listed explanatory variables. Intercept terms and year dummies are included for all regressions, but not reported. (P-values are in parentheses).

\begin{tabular}{|c|c|c|c|}
\hline \multirow[b]{2}{*}{ Variables } & \multirow{2}{*}{ All Sample } & \multicolumn{2}{|c|}{ Subsidiaries with } \\
\hline & & ROA $>$ median & ROA $<$ median \\
\hline \multirow{2}{*}{ Own cash flow } & 0.1267 & 0.2627 & 0.1516 \\
\hline & $(0.0003)$ & $(0.0009)$ & $(0.0070))$ \\
\hline \multirow[t]{2}{*}{ Other cash flow } & 0.0178 & 0.0134 & 0.0335 \\
\hline & $(0.0010)$ & $(0.0032)$ & $(0.0040)$ \\
\hline \multirow[t]{2}{*}{ Own ROA } & -0.0011 & -0.0017 & -0.00135 \\
\hline & $(0.0006)$ & $(0.0009)$ & $(0.0117)$ \\
\hline \multirow[t]{2}{*}{ Highest ROA } & -0.0009 & -0.0005 & -0.00145 \\
\hline & $(0.0004)$ & $(0.1318)$ & $(0.0022)$ \\
\hline \multirow[t]{2}{*}{ FFA } & -0.0735 & -0.0107 & -0.11475 \\
\hline & $(0.0026)$ & $(0.6158)$ & $(0.0218)$ \\
\hline \multirow[t]{2}{*}{ Group size } & -0.0137 & -0.1032 & 0.0393 \\
\hline & $(0.5991)$ & $(0.0001)$ & $(0.3731)$ \\
\hline $\mathrm{R}^{2}$ & $17.51 \%$ & $30.76 \%$ & $28.38 \%$ \\
\hline $\mathrm{N}$ & 434 & 217 & 217 \\
\hline
\end{tabular}


Table 3: Panel data regression with fixed effects of the investment of all subsidiaries from 1991 to 1996 as a linear function of listed explanatory variables. Intercept terms and year dummies are included for all regressions, but not reported. (P-values are in parentheses).

\begin{tabular}{|l|cc|}
\hline \multirow{2}{*}{ Variables } & \multicolumn{2}{|c|}{ Holdings with } \\
& $\begin{array}{c}\text { Low credit constraint } \\
\left.\text { (high ratio } \frac{C F_{K}}{T A_{K}}\right)\end{array}$ & $\begin{array}{c}\text { High credit constraint } \\
\left.\text { (low ratio } \frac{C F_{K}}{T A_{K}}\right)\end{array}$ \\
\hline Own cash flow & 0.2415 & 0.1179 \\
Other cash flow & $(0.0506)$ & $(0.0233)$ \\
& 0.0127 & 0.0189 \\
Own ROA & $(0.0753)$ & $(0.0337)$ \\
& -0.0021 & -0.0011 \\
Highest ROA & $(0.0046)$ & $(0.0251)$ \\
& -0.0006 & -0.0010 \\
FFA & $(0.1645)$ & $(0.0111)$ \\
& -0.0353 & -0.1323 \\
Group size & $(0.3070)$ & $(0.0020)$ \\
& -0.0390 & 0.0304 \\
\hline R & $(0.2796)$ & $(0.4850)$ \\
N & $24.13 \%$ & $22.42 \%$ \\
\hline
\end{tabular}


Table 4: Panel data regression with fixed effects of the investment of all subsidiaries from 1991 to 1996 as a linear function of listed explanatory variables. Intercept terms and year dummies are included for all regressions, but not reported. (P-values are in parentheses).

\begin{tabular}{|l|cc|cc|}
\hline \multirow{2}{*}{ Variables } & \multicolumn{2}{|c|}{ Holdings with } & \multicolumn{2}{c|}{ Coordination center } \\
& 2 to 4 subsidiaries & 5 or more subsidiaries & Yes & No \\
\hline \multirow{3}{*}{ Own cash flow } & 0.03753 & 0.5241 & 0.4564 & 0.08044 \\
& $(0.1123)$ & $(0.0000)$ & $(0.0000)$ & $(0.1584)$ \\
Own ROA & -0.0046 & 0.0135 & 0.0179 & 0.0069 \\
& $(0.4525)$ & $(0.1664)$ & $(0.0128)$ & $(0.4180)$ \\
Highest ROA & -0.0003 & -0.0052 & -0.0045 & -0.0007 \\
& $(0.1469)$ & $(0.0000)$ & $(0.0000)$ & $(0.1802)$ \\
FFA & -0.0003 & -0.0008 & -0.0008 & -0.0008 \\
& $(0.1384)$ & $(0.1350)$ & $(0.0521)$ & $(0.1242)$ \\
Group size & -0.0287 & -0.0531 & -0.0326 & -0.0944 \\
& $(0.1052)$ & $(0.1402)$ & $(0.3377)$ & $(0.0070)$ \\
\hline $\mathrm{R}^{2}$ & -0.0008 & -0.0118 & -0.0189 & 0.0248 \\
$\mathrm{~N}$ & $(0.9646)$ & $(0.8615)$ & $(0.6418)$ & $(0.5841)$ \\
\hline
\end{tabular}




\section{References}

[1] Aggarwal, R. and Samwick, A., (2003) Why Do Managers Diversify Their Firms? Agency Reconsidered, Journal of Finance, 58, 71-188.

[2] Brusco, S. and Panunzi F., (2003) Reallocation of Corporate Resources and Managerial Incentives in Internal Capital Markets, forthcoming European Economic Review.

[3] Berger, P. and Ofek, E., (1995) Diversification's Effect on Firm Value, Journal of Financial Economics, 37, 39-65.

[4] Campa, J-M. and Kedia, S., (2002) Explaining the Diversification Discount, Journal of Finance, 57, 1731-1762.

[5] Chevalier, J. (2004) What Do We Know About Cross-subsidization? Evidence from Merging Firms, Advances in Economic Analysis \& Policy, Vol. 4, No. 1, Article 3.

[6] Colmant, B., A. Detournay and Servaty, L., (2003) La décote boursière des holdings belges, Editions Larcier, Brussels.

[7] Deloof, M., (1998) Internal Capital Market, Bank Borrowing, and Financial Constraints: Evidences from Belgian Firms, Journal of business finance and accounting, 25, 945-968.

[8] Deloof, M., (2001) Belgian Intragroup Relations and the Determinants of Corporate Liquid Reserves, European Financial Management, 7, 375-392.

[9] Doukas, J., Holmen, M. and Travlos, N., (2002) Diversification, Ownership and Control of Swedish Corporations, European Financial Management, 8, 281-314.

[10] Fazzari, S., Hubbard, R. and Petersen, B., (1988) Financing Constraints and Corporate Investment, Brookings Papers on Economic Activity, Volume 1, 141-195.

[11] Fleming, G., Oliver, B. and Skourakis, S., (2003) The Valuation Discount of Multi-Segment Firms in Australia, Accounting and Finance, 43.

[12] Gautier, A. and Heider, F., (2002) The Benefits and Costs of Winner Picking: Redistribution Vs Incentives, Bonn Graduate School of Economics discussion paper 31/2002.

[13] Guertner, R. Scharfstein, D. and Stein, J., (1994) Internal versus External Capital Markets. Quarterly Journal of Economics, 109, 1211-1230. 
[14] Inderst , R. and Laux, C. (2001), Incentives in Internal Capital Markets: Capital Constraints, Competition, and Investment Opportunities, London School of Economics and Political Science (LSE).

[15] Jensen, M.C., (1986) Agency costs of free cash flow, corporate finance and takeovers, American Economic Review, 76, 323-339.

[16] Lamont, O., (1997) Cash flow and Investment: Evidences from Internal Capital markets, Journal of Finance, 52, 83-109.

[17] Lamont, O. and Polk, C., (2002) Does Diversification Destroy Value? Evidence from Industry Shocks, Journal of Financial Economics, 63, 51-77.

[18] Lang, L. and Stulz, R., (1994) Tobin's q, Corporate Diversification and Firm Performance, Journal of Political Economy, 102, 1248-1280.

[19] Lins, K. and Servaes, H., (1999) International Evidences on the Value of Corporate Diversification, Journal of Finance, 54, 2215-2239.

[20] Lins, K. and Servaes, H., (2002) Is Corporate Diversification Beneficial in Emerging Markets? Financial Management 31, (-31.

[21] Maksimovic V. and Phillips, G., (2002) Do conglomerate firms allocate resources inefficiently across industries?, Journal of Finance, 57, 721-767.

[22] Praet. A., (2002) The efficiency of Security Substitution by Diversified Holding Companies in Belgium.

[23] Rajan, R. Servaes, H. and Zingales, L., (2000) The cost of Diversity: The Diversification Discount and Inefficient Investment, Journal of Finance, 55, 35-84.

[24] Scharfstein, D., (1998) The Dark Side of Internal Capital Markets II: Evidences from Diversified Conglomerates. NBER WP 6352.

[25] Scharfstein, D. and Stein, J., (2000) The Dark Side of Internal Capital Markets: Divisional Rent-seeking and Inefficient Investment, Journal of Finance, 55, 2537-2564.

[26] Shin, H. and Stulz, R., (1998) Are Internal Capital Markets Efficient?, Quarterly Journal of Economics, 113, 531-553.

[27] Siaens, A. and Walravens, M., (1993) Valorisation d'un holding: Le problème de la décote, Revue de la Banque, 6, 305-313. 
[28] Stein, J., (1997) Internal Capital Markets and Competition for Corporate Resources, Journal of Finance, 52, 111-133.

[29] Van Cayseele, P., (2002) Investment, R\&D and liquidity constraints, Working Paper 33, National Bank of Belgium.

[30] Villalonga, B., (2004a) Does diversification cause the diversification discount?, Financial Management, 33, 527.

[31] Villalonga, B., (2004b) Diversification discount or premium? New evidence from the Business Information Tracking Series, Journal of Finance 59, 475502.

[32] Williamson, O., (1975) Markets and Hierarchies: Analysis and Antitrust Implications, Collier Mac Millan Publishers Inc, New York.

[33] Wymeersch, E., (1994) Institutional Investors, Financial Groups and their Impact on Corporate Governance in Belgium, in: Institutional Investors and Corporate Governance, (Th. Baums, R.M. Buxbaum en K.J. Hopt, eds.), De Gruyter, Berlin, 347-384. 